Sign Systems Studies 48(1), 2020, 12-31

\title{
Creating reality as a locally tailored interface - an integrational, pragmatic account of semiosis
}

\author{
Charlotte Conrad ${ }^{1}$
}

\begin{abstract}
Linguistics and semiotics traditionally assert the view that communication presupposes signs. Integrational linguistics challenges this notion by refuting the firstorder ontological status of signs and semiological codes. Yet if communication does not depend on pre-established signs, then how does semiosis proceed? And what is the basis for the intuitively acceptable notion that codes do exist as socially carried structures among living beings? In this article I present an integrational account of semiosis based on the suggestion that sign-making is a perceptual activity. I draw on William James' concept of human experience to expound Roy Harris' claims for the radical indeterminacy of the sign, for contextualization, and for the process of integration. In closing, I consider the role that mental associations, for example, those between language sounds and concepts, play in communicative activity.
\end{abstract}

Keywords: semiosis; integrationism; pragmatism; perception; contextualization; radical indeterminacy of the sign

\section{Introduction}

Roy Harris is best known for his provocative and well-argued revolt (for an analysis, see Cobley 2011) against the traditional linguistic idea that a 'language' is an ontologically independent semiological structure that governs the actual acts of communication in a linguistic community (Harris 1981, 1996a, 1998). While Harris' argument carries the most direct impact to the scientific foundation of linguistics, the claims he makes clearly have consequences beyond the language sciences.

All signs, says Harris, granted that we understand them as semiologically active phenomena, exist only in the individual sign-maker's consciousness during the fleeting moment of sign-making. And here, they are made in contextually contingent ways which render them radically indeterminate to any other than the

1 Independent scholar, Dubai; e-mail: cskibdalconrad@gmail.com. 
first-person perspective. Harris further claims that "there is no single all-purpose conception of the sign that fits all intellectual enterprises" (Harris 2009: 61). By these claims, integrationist semiology obviously challenges the soundness of all discussions that grant signs ontological autonomy and permanent, context-free identity - as does, for example, most of the research that has established semiotics as a successful research field since the mid-20th century. It is not clear, however, what exact consequences integrationism carries to semiotic inquiry. Integrationist theory is still evolving, and so far it has taken away the notion of pre-existing signs without presenting an account of semiosis detailed enough to explain how people are able to communicate successfully, and in ways that yield to the fallacy of thinking that culturally shared semiological codes do exist.

In this article I present an integrational account of semiosis that does not presuppose signs, but explains them as emergent within human perceptual activity. The account is delivered by expounding Harris' claims for the radical indeterminacy of the sign, for contextualization, and for the process of integration. It also mentions the role that mental associations, between language sounds and concepts, for example, play in communicative activity.

The account is rooted in pragmatic ideas on how we perceive the world. I suggest that the American pragmatists presented an understanding of human experience that allows us to understand the inner dynamics of human semiosis when it is seen as the creation of radically indeterminate signs. In the writings of William James this understanding is expressed in sufficient detail to inspire a fundamental account of integrational semiosis.

\section{The radical indeterminacy of the sign}

A central tenet of integrationism is that the signs human beings make are radically indeterminate. Neither their form nor meaning can be realized from a perspective outside the sign-makers perspective in the local moment of sign-making. The fundamental integrationist premise for claiming indeterminacy is Harris' realization that acts of communication are ontologically prior to the creation of signs. Communication processes do not wait for a set of fixed signs to be available, signs are created in and by the act of communication:

Integrational semiology starts from the premise that signs occur in and as the products of communication processes. Given that no communication is contextless and that all communication is uniquely contextualized (the participants being time-bound agents), it follows that signs also are unique. (Harris 1996a: 154) 
In Harrisian semiology the sign-maker's perception of context is thus a determinative factor in the sign-making act. What I am going to suggest in the following is that human perceptual ability can account even more fully for sign-making without claiming a predefined sign - granted the employment of an appropriate understanding of perception.

The human faculty for perception, seen as "the process whereby sensory stimulation is translated into organized experience" ${ }^{2}$, has historically been subject to much debate in Western philosophy and psychology. A consensus around perceptual realism has historically been dominant, but today some form or degree of relativism in human perception is generally recognized across academia - we see it serving as an important tenet in the established epistemology of the natural sciences (i.e. in the critical rationalism of Karl Popper) and find it explored in the current enactivist wave in cognition studies which talks of reality as completely relative to - enacted by - the individual perceiving and interacting individual (e.g. Varela, Thompson, Rosch 1991; Noë 2004).

In this light, one might not expect current semiological theory to incorporate ideas of an autonomous reality being diaphanously perceived. Yet proposing signs to be stable prerequisites for communication - as the thinking in "semiological codes" presented in mainstream linguistics, semiotics and biosemiotics does depends at least on the notion that pre-established expressive forms have independent and objective existence and somehow wander unhindered and uncompromised into the individual sign-making mind on each occasion of comprehension.

Arguably, mainstream Western thoughts on language, knowledge, ontology and perception hold one another in a mutually restrictive pattern orchestrated by an incredibly consequential interest in attaining absolute knowledge of external reality. ${ }^{3}$ Integrationism, by claiming radical indeterminacy of signs, breaks free from this thought pattern, and accordingly I suggest that traditional perceptual theory will not be able to sustain it. In the interest of arguing for my choice of an alternative concept of perception to sustain integrational semiology, I will refer to the historical development of thoughts on perception in what follows.

When Aristotle portrayed language in his Poetics, he cast it as a fixed code for the immaculate transfer of thoughts based on the philosophical idea that all men carry in their minds the same impressions of worldly things tied to the same language sounds (Harris 1981). To Aristotle man was not the true epistemic agent

2 Dember, William N.; Epstein, William; West, Louis J. Perception. Encyclopedia Britannica. (https://www.britannica.com/topic/perception) was accessed in August 2019.

3 For a thorough exploration of the interdependency of the Western concepts of language and philosophy, please see Harris 1996b. 
per se: divine ratio operated through him, grasping or rather, adapting its shape to, the eternal form, the essence or organizing principle (logos) of things (pragma) in the world. In Aristotle's Theory of Language and Meaning, Deborah K. Modrak (2000: 177) explains that, to Aristotle, the logos in the thing was the same logos available to the rational mind: "By making the logos (formula) that is asserted by the definiens the very same form as the logos that is realized in matter, Aristotle hopes to secure the unity of the definition and the intelligibility of the substance".

According to Modrak there is a specific philosophical purpose for the notion of the world as an assembly of stable, ontological forms:

The ontological requirements of language and knowledge, as Aristotle understands
them, are such that enduring characteristics of mutable and transient individuals
are needed. This prompts Aristotle to identify forms, in contrast to concrete
particulars, with primary substance in the central books of the 'Metaphysics' and
to develop an account of the relation between form and matter that is informed at
every stage by a concern with linguistic definition and a conception of essence as
the exemplary object of knowledge. [...] At every stage, the description of ontology
is guided by the requirement of rational accessibility. Not only must the ontology
be intelligible from a theoretical perspective, it must be accessible at the pre-
theoretical level of perception and ordinary language. (Modrak 2000: 175)

Stable, enduring forms and the notion that they are immaculately realized, allows the philosophical society to access the world directly and keep the eternal truth of the cosmos alive in the fixed code of language. At the later point in European history when empirical science is inaugurated as the gateway to true knowledge of the world, it is arguably the very same consideration that ultimately causes a transformation of the concept of human experience: Dewey writes about how, in the times of Plato and Aristotle, the senses of man were thought to relate the world to the body:

The senses are connected with the appetites, with wants and desires. They lay hold not on the reality of things but on the relation which things have to our pleasures and pains, to the satisfaction of wants and the welfare of the body. They are important only for the life of the body, which is but a fixed substratum for a higher life. (Dewey 1916: 309)

But when the body is called to centre stage as the empirical gateway to new truth, perception's connection to individual needs and desires is looked at as a detriment (Bordo 1987). Philosophers marred by Cartesian angst were not in search of a less determinate and universally true knowledge than the one lost to religious war and disturbing cultural, geographical and cosmological discoveries. And so the senses 
had to be methodically wielded for and controlled ("delivered and reduced", as Francis Bacon ${ }^{4}$ said) to deliver truth. Dewey (1916: 312) writes that in the 17th and 18 th centuries "[e]xperience lost the practical meaning which it had borne from the time of Plato. It ceased to mean ways of doing and being done to, and became a name for something intellectual and cognitive. It meant the apprehension of material which should ballast and check the exercise of reasoning". At the same time "the interest in experience as a means of basing truth upon objects, upon nature, led to looking at the mind as purely receptive. The more passive the mind is, the more truly objects will impress themselves upon it" (Dewey 1916: 312).

The scientific revolution thus established human experience as the passive reception and association of objective sense impressions. In other words, the philosophers kept the world stable as an atomistic assembly of absolute objects with the one hand, while human bodily perception was forced into a diaphanous shape by the other. Knowledge, and its containment in the fixed code of language was thereby kept safe.

Later again, prominent thinkers like Kant, Hegel and Darwin each in their way destabilized the fixed universe and the direct access to it. The writings of Darwin, or of evolutionist thinking in general, were possibly the most disturbing. Evolutionists cast the human being as evolved in a struggle to survive in nature, and so his abilities would be adapted to serve interaction - not truth. By the end of the 19th century adverse feelings towards the classic modern epistemological concepts had grown so strong that several seminal philosophical movements with defining influence on 20th-century thought and academic culture were born from them. The humanist sciences and phenomenology for example are respectively spurred by Dilthey's and Husserl's initial dissatisfaction with the sterile philosophical explanation of experience so remote from actual life (Landgrebe 1973; Dilthey 1988). The pragmatists, who gathered in a discussion forum they called 'the Metaphysical Club', were in no way the only ones to turn their backs to what Dewey called the philosophical fallacy - the a priori idea that human beings are merely spectators of a world to be known.

And so, in this spirit, new understandings of human perception as somehow relative to the human condition present themselves in philosophy and other academic fields in the 20th century. Many of the new theories are imbued with a longing to reach back behind the relativity to the absolute truth out there. Philosophers talk of percepts in the abstract as timeless mental states (Bertrand Russell, George E. Moore) and their focus is rather on how these mental states relate to truth than to the individual perceiver's personal needs and purposes. Or

4 Bacon, Francis 1605. The Advancement of Learning, Book II, XIV, 9. 
they describe perceptions beyond individuals, as in species-specific accounts of perception (e.g. Jakob von Uexküll, James Gibson) thus safeguarding traditional accounts of truth and knowledge. William James' pragmatic account of human experience however presents a radical departure from attempts to fix perception beyond the individual perceiver. To James, no worldly forms, neither objective nor species-specific, are presupposed when it comes to experience: the forms that reality takes, both as regards the perceiver and the perceived, are locally emergent in the meeting between world and individual, as both parties have a hand in the game:

We conceive a given reality in this way or in that, to suit our purpose, and the reality passively submits to the conception.You can take the number 27 as the cube of 3 , or as the product of 3 and 9 , or as 26 plus 1 , or 100 minus 73 , or in countless other ways, of which one will be just as true as another. You can take a chess-board as black squares on a white ground, or as white squares on a black ground, and neither conception is a false one.

You can treat the adjoined figure [Figure of a 'Star of David'] as a star, as two big triangles crossing each other, as a hexagon with legs set up on its angles, as six equal triangles hanging together by their tips, etc. All these treatments are true treatments - the sensible that upon the paper resists no one of them. You can say of a line that it runs east, or you can say that it runs west, and the line per se accepts both descriptions without rebelling at the inconsistency. [...]

In all these cases we humanly make an addition to some sensible reality, and that reality tolerates the addition. All the additions 'agree' with the reality; they fit it, while they build it out. No one of them is false. Which may be treated as the more true, depends altogether on the human use of it. If the 27 is a number of dollars which I find in a drawer where I had left 28 , it is 28 minus 1 . If it is the number of inches in a board which I wish to insert as a shelf into a cupboard 26 inches wide, it is 26 plus 1 . If I wish to ennoble the heavens by the constellations I see there, 'Charles's Wain' would be more true than 'Dipper.' (James 1907: 251-253)

What shapes the form and meaning of a person's reality is the practical purpose that he holds:

What shall we call a thing anyhow? It seems quite arbitrary, for we carve out everything, just as we carve out constellations, to suit our human purposes. For me, this whole 'audience' is one thing, which grows now restless, now attentive. I have no use at present for its individual units, so I don't consider them. [...]. The permanently real things for you are your individual persons. To an anatomist, again, those persons are but organisms, and the real things are the organs. Not the organs, so much as their constituent cells, say the histologists; not the cells, but their molecules, say in turn the chemists. 
We break the flux of sensible reality into things, then, at our will. We create the subjects of our true as well as of our false propositions.

We create the predicates also. (James 1907: 253-254)

The reality shaped relative to a person's purpose in the moment of perception carries influence to his practice. James mentions (quoting Wilhelm Ostwald) this influence as 'meaning': "All realities influence our practice, [...] and that influence is their meaning for us" (James 1907: 48).

Perception to James is an activity which configures (to James, 'carves out') the world into meaningful forms for the individual perceiver in the moment of perception. Perception is an evolved ability to transform an initial indeterminate field of impressions (James calls it "pure experience" a "blooming buzzing confusion" - James 2003[1912]: 49) into a perceived interaction space in which things have taken shape relative to oneself and one's purpose. Perception thus creates a locally specified, tailored, interface between a person and the world which facilitates action in pursuit of some purpose. In other words, perception serves and informs a person's ability to act in the world by allowing purpose-relative forms and their meanings to emerge.

The Jamesian account of perception, I suggest, presents itself as a suitable candidate for explaining the psychological dynamic in the semiosis of radically indeterminate signs. To James, no worldly forms predetermine the form of a percept or its meaning, just as no worldly forms or pre-established signs predetermine the forms and meanings of the integrational sign. To James, the individual perceiver is actively and creatively involved in perception, just as Harris' individual sign-maker is actively and creatively involved in sign-making. To James, percepts are made to inform action and to Harris, signs equally inform action in that they integrate activities, i.e. they make something mean something to someone with regards to a further sequence of activity. In short, I suggest that James' experiential theory can explain the inner dynamics in the sign-making process which is currently missing from the integrational account. Sign-making happens - in perception - when an agent carves out a perceptual form and determines its meaning relative to his purpose and situation.

Would Harris be sympathetic to granting that a pragmatic theory of experience could account for sign-making? The answer may depend on when he would have been asked. In 1996, he is arguing against the notion that sign-making happens in perception, seemingly wanting to reserve a level of undisturbed pure contact with reality as prior to sign-making: 
[...] what is the difference between self-communication and simply being conscious of one's own sensory experience? For the integrationist, all communication involves signs of some kind and signs are what we make them and what we make of them. They are not supplied by Nature. The difference lies there. (Harris 1996a: 173)

When I dip my toe in the water I simply feel something which is wet and hot, or cold or lukewarm, etc;; but these sensations and my judgments as to the wetness, heat, etc. require no intermediating sign. Nor do they have any semiological function at all until I treat them as signs for purposes of some further activity. (Harris 1996a: 177)

Yet this position seems to run counter either to the tenet of the radical indeterminacy of the sign, or to an evolutionist rationale. If worldly things forced themselves on perception in a particular form and were made into signs in that form, then semiotic forms would in fact be predeterminable. If perception would rather consistently have to overrule initially perceived particular forms in order to outline the shapes that make the world interactable to a purpose-directed person, then perception would deliver a terribly ineffective feed to sign-making.

Would I be able to quickly figure a pathway through the park if it was made by millenia of pebbles each of which became individually present to me first? And would I ever see a portrait of a man in the renaissance painting of vegetables by Arcimboldo, if all the vegetables first imposed themselves independently on my senses?

As it happens, in Integrating Reality, a work published in 2012, Harris has let go of the commitment to a readymade and preformed human reality that imposes itself onto the mind through the senses: "[...] reality does not come equipped with its own natural classifications that are then imposed willy-nilly on speakers and writers" (Harris 2012: 20-21) and "[...] reality is misconceived when regarded as some kind of universal psycho-physical bedrock on which human lives and activities ultimately rest" (Harris 2012: 38).

Harris, in 2012, works with an ontological commitment to reality as a product of integration: “integrationism's main ontological commitment is to language as the principal means of integrating reality" (Harris 2012: 111); "what we call 'reality' is nothing other than its integration in our sensory experiences" (Harris 2012: 21).

Integration creates reality, and how we perform the act of integration, how we from (linguistic or other) impressions provided by our senses create forms and meanings in the reality we experience, is not given in advance of who does it or the communication situation he or she is in. Integration is done through sign-making and signs are radically indeterminate. 
In this way, to both Harris, writing in 2012, and to James, there is, in the creation of experienced reality, a shaping of experienced forms and meaning going on relative to the individual human being engaged in a practical activity or by a practical purpose. James calls it perception, Harris calls it integration. I stipulate that they are talking about the same psychological happening.

Take Harris' example of sign-making while driving home one day. He writes: "I know, for example that on my way home, by the time I have moved up into third gear from the traffic lights by the bridge, it is time to start signalling for my right turn by the church on the next corner" (Harris 1996a: 173). To Harris with the purpose of reaching home, the action of moving into third gear while accelerating after the traffic lights by the bridge is integrated with the act of remembering or knowing that it is time to start signalling right. These acts are integrated as Harris makes something in his experience a sign, say, for example, that he makes the experience of moving into third gear mean that it is time to use the turn signal, which he subsequently does.

Now let us ask Harris to offer the wheel to James, whom we can imagine sitting now in the same car on the same road in London driving home, moving up into third gear from the traffic lights by the bridge, and knowing that it is time to start signalling for his right turn by the church on the next corner. To James, perception would involve carving out phenomena as meaningful (influential to) his practice. While driving he could for example carve out 'the move into third gear after the traffic lights by the bridge' as a phenomenon which influences his practice so that he remembers to use the turn signal. James could also perceive the phenomenon of 'the car accelerating' as having the influence on his practice to decrease his push at the speeder. Of course he could also perceive 'the wheel' as a phenomenon which allows him to steer the car straight towards the next turn, etc., etc.

In both accounts meaningful phenomena are given shape in experience, relative to purpose. James' account may remind us that sign-making happens a lot more often than what traditional semiologies seem to suggest. But that does not retract from the fact that the singular action of making a sign and perceiving something as meaningful seems to be the same. 


\section{Creating radically indeterminate form and meaning}

In the following section I build on James' account of experience, extrapolating from it when needed in order to inform an integrational account of semiosis.

Seeing as interaction never happens with one thing in isolation from all else, perception would not be efficient if it shaped each thing without regard for whatever else is present. Forms jointly serve our interactional purpose. The question that perception can implicitly be said to answer when forms and meanings arise in an experienced reality thus can not be: "What form does this thing have relative to my kind?" and "What is the interaction potential between me and this thing?". This perceptual idea seems to be presupposed for example in the affordance theory of James Gibson.

How a boy who is climbing up the walls in a hallway, creating leverage by pushing his feet against one wall and his hands against the opposite wall, perceptually outlines the particular area further up the wall that - if he moves his hand there - will allow him support to climb again, depends on his current position and the perceived features of his body, the length of his arms and the strength that he has for example. And how I will understand something you say to affect my interaction potential, can, for example, depend on who else is present. Perception then must, if we are to keep our understanding of perception in line with evolutionary principles, implicitly answer the question: "In which form(s) and how does the world affect my interaction potential with the situation I am in?"

Looking at sign-making as perception, then - perhaps unsurprisingly - tells us that the sign is formed relative to our purpose as well as to other factors in the situation perceived. The fact that we are not trying to figure out how to interact with one thing only, but with a dynamic of things in our surroundings, also tells us that we do not see a simple relation between ourselves and the thing we perceive, but a relativity between more factors. When we experience a thing, we see how it affects our interaction potential with a situation. Thus, meaning does not point back to the form, as in binary linear definitions of signs. Meaning is an effect on the interaction potential towards some goal or purpose, and as such points beyond itself. Harris catches this sense of meaning in the idea of integration: "Speech sounds have no meaning unless and until they can be integrated, just like other signs, into the process of making sense of some particular episode in the continuum of human experience" (Harris, Wolf 1998: 19). 


\section{Contextualization and integration}

How do we contextualize a sign? Harris himself called for further investigation of this question:

Contexts are not 'given': they are constructed by the participants in particular communication situations. How exactly this is done - how the distinctions are drawn between what is relevant and what is not - no one has yet explained. Integrational research aims to explore this problem. ${ }^{5}$

For certain, contexts are not objectively definable: "[...] context is not some specific set of background facts which contribute to, or are presupposed by, this or that episode of communication" (Harris 1998: 104).

Contexts are "always the product of contextualization, and each of us contextualizes in our own way, taking into account whatever factors seem to us to be relevant" (Integrationist notes and papers 2006-2008, here from Pablé, Hutton 2015). We may not even be aware exactly how we contextualize: “[...] an integrationist would point out that it is far from clear that participants themselves always know which particular details or combinations of details in an episode of communication led them to interpret it as they did" (Harris 1998: 98).

When we consider semiosis in the light of James' pragmatic account of perception, some features of contextualization do seem necessary - and thus in fact pre-determinable - not in content, but in theme, but they are not the more traditional ideas of time and place (e.g. Linell 2009) (see below as concerns the principle of co-temporality). Rather they are ideas of agency and purpose. In James' description of perception, meaningful things in the world are always carved out relative to agent and purpose. It follows that these two percepts must become clear before anything else in perception. Accordingly, in an integrational account of semiosis we would say that the percepts of agent and purpose are the minimal and primary constituents of context.

Furthermore, if perception is to serve interaction well, it must assure that meaningful percepts are adapted - not only to the interacting agent's local constitution and purpose, but also to any other perceived meaningful factors that will affect interaction in the purposed direction. The sign I make from perceiving my bike when I look outside needs to be adapted to the fact that I am sick and want to go to the doctor as well as to the fact that it is raining.

5 Harris, Roy. Integrationism, a very brief. introduction. Point 4c. Retrieved from https:// www.royharrisonline.com/integrational_linguistics/integrationism_introduction.html. 
It may be non-controversial to say that semiosis does not happen without an agent. It is important to note, however, that it follows from looking at signmaking as a perceptual activity that the agent's purpose is an equally indispensable phenomenal factor for effective sign-making.

You can verify this as easily as by walking up a street. When I, walking down the main street in the small town I grew up in, want to go to my parents' house, arriving at the "library square with the fountain on it" can affect my interaction potential so as to make me want to turn left down the next side street. As soon as I halt my step realizing I left my bag on the train and start considering what to do now, I am still in that same spot on the square, but to me the square has lost its integrational value. I may configure it again as a point of departure to find my direction back to the train station once I set myself a new goal. But the semiologically active sign is only to be found in the space between the agent, situational phenomena and purpose.

The claim that sign-making is guided by a practical purpose, which follows from regarding sign-making as a perceptual activity, matches Harris' statement that the integration of activities is accomplished by sign-making. To Harris, it counts for all communication that: "One activity or complex of activities is to be integrated with another in a particular set of circumstances" and "what integration there is, in any given circumstances, proceeds by the means of signs" (Harris 1996a: 12). From a first-person point of view, placed in the midst of action, the sign-maker will hardly experience sign-making as an "integration of activities", though. Viewing something as an activity - as a series of movements towards some goal - demands distance from the activity itself. Integrating the activity that came before with the activity that comes next, may be done reflexively in thought, but immersed in the experiencing body during action, what is needed, is that the signmaker focus on figuring out the interaction potential ahead, i.e. the sign-maker needs to be guided by a purpose, in order to make signs.

The agentive purpose that constrains contextualization is not necessarily a conscious goal. An agent may be aware that he is "folding clothes" while talking to a friend on Skype, but the action of folding clothes has a series of subgoals. For example, folding a shirt may involve first straightening the fabric with smoothing hands and then folding in the sides in straight lines, and then folding the top towards the bottom of the shirt. Even if all of these subtasks move the agent towards the same goal (of folding the shirt), mixing these tasks up would cause inefficient interaction. To gather only the relevant constraints on signmaking contextualization must employ the right goal in each sign-making act. So while the agent may think, and say, that he is folding laundry, the goal that is actually constraining his sign-making may be the goal of folding the top of the 
shirt towards the bottom of the shirt. And as in human life activities are often convoluted, concurring or overlapping and even conflicting, an important task of the perceiving mind must be to keep track of, organize and manage the goal that becomes active when an agent contextualizes signs to guide action.

Obviously we do not hold very clear goals at all times, and we do manage to be in the world when we do not. Are we not sign-making in those situations? I reckon that we sometimes have quite broad goals, such as just sitting comfortably. In those cases, the seat affecting the way we balance our bodies when holding an upright position may be the only sign we make. In cases of meditation we may be striving towards making as few signs as at all possible, not moving and not thinking. Sign-making integrates activities - in the mind or in the world.

During an experience, each meaningful percept I outline - each sign I make by regarding a phenomenon as significant to my interaction potential towards my current goal can make part of the context for further perception (sign-making) as I move towards my goal. If I first integrate the air to be moved through while moving towards the bookshelf to pick up a book, the air and the bookshelf are still signs to me as I configure the floor path to walk there. If they were not, I would not be able to guide my interaction effectively. Radically indeterminate sign-making is thus seen to be in no way random and unguided, but facilitated by contextualization, making it a locally constrained operation.

In short, I suggest that in perception, signs are contextualized as perception first outlines an agent and a projected purpose or goal. These two percepts establish a minimal understanding of the situation. When the situation is formed, the process of sign-making allows the agent to understand a phenomenon as significant to his interaction in pursuit of the goal. Once a sign is formed it may take part in the contextualization of a new sign. Integration of signs into a consistently adjusted context can in this way proceed until the local goal or the perception of agency changes. In other words, by perceptually outlining agent and purpose, the perceiver establishes the first basis for understanding the world as a constraint to his interaction potential. He starts creating reality as a local interface tailored to himself and his purpose.

Contextualization and semiosis are indispensable parts of the same perceptual act towards realizing interaction potential in a local pursuit of a purpose: "Signification and contextualization are not two independent elements but facets of the same creative activity" (Harris 1996a: 164). 


\section{The quality of perceptual signs and contexts}

It is important to note that both agency and goal, and phenomena to be interacted with (perceptual forms with meaning) are emergent in the moment of contextualization and sign-making as they must be adjusted relative to each other in order to aid interaction adequately. Even the idea of the agency that a person forms of himself, will ideally be adapted in every new situation so that relevant features are drawn forth and irrelevant features are pushed back. The agent can perceive himself as part of an agency, a group with a joint purpose, or perceive his body as prolonged or extended into an instrument such as a hockey stick or a car. The phenomenal factors that go into contextualization and sign-making can cut across sensory impressions, memory and imagination. Seeing the top of your head when I gaze down to see who is ringing the doorbell, will demand me to use memory to establish the whole of you as a sign to affect my further interaction of running downstairs to open the door.

A perceived context is not necessarily tied to local time and space either. Even yesteryear's happenings in Africa that I have only heard of, but remember, can be integrated as a sign in my growing understanding of how to interact with a person I will meet tomorrow. Harris states that contextualization, like all other aspects of communication, is subject to the 'principle of co-temporality', which he explains as the principle of being "limited by what, at any given time, participants are aware of" (Harris 1998: 105). He writes: "the chronological integration of language with events in our daily lives requires us to suppose that what is said is immediately relevant to the current situation, unless there is reason to suppose otherwise" (Harris 1998: 81).

However, whenever some situation can be expected to be more salient in the mind of the person who is speaking to you, you will contextualize accordingly. If a close relative has been in a car accident and you enter home where your wife is in the kitchen, it may well be immediately obvious to her when you inquire: "how is he?" that you mean your relative rather than the dog who is present in the kitchen and usually the subject of concern.

Only as material beings are we timebound agents. Minds hold no such borders. We can travel in possible, projected, imagined, wanted, past worlds, all while our bodies remain in the confines of a local moment in a day. The people we communicate with can do the same, and we exploit that in communication. 


\section{Mental associations and semiosis}

How does the present account of sign-making match the intuitive notion that pre-established associations - say, between language sounds and concepts - play an important part in our ability to communicate? Harris does not refrain from using the term 'word' in his writings. It is clear that he does not think of words in a traditional structuralist sense as indivisible ideal units of sound and meaning. Rather, words must be thought of as second-order constructions - percepts that are decontextualized, abstracted and reified (see Love 2007: 705) from earlier 'firstorder' experiences of successful communication. These second-order constructs can inform new instances of communication:

[...] what we learn as the names of 'real' things embody the views of earlier generations about the way our language relates to the world. Realia is a collection of these hallowed assumptions, which, as learners, we have no way of challenging. Nor do we seek to, because these inherited assumptions are effective in integrating our discourse both with that of our elders and with that of our contemporaries. So eventually we lose any sense of their conventionality, and treat them as reflecting the world 'as it is' and not as an arbitrary verbal lens through which we have been brought up to see things. So if we have learnt to count and to identify pieces of furniture, saying 'There are three chairs in the room' seems a natural way of speaking, objectively dictated by what is really the case, i.e. the presence of three chairs in the room. Anyone who checked this by counting the chairs again would be sure, barring mistakes of arithmetic, to find the assertion impeccable, provided he used words in the same way. (Harris 2012: 15)

Learning to cope in a dynamic world depends on understanding functional relations and being able to be guided by this understanding in the experience of new situations. This counts for meetings with polar bears as well as in everyday situations. Think of a golf player. Experience tells her that a particular direction of her feet relative to the flag she is targeting (i.e. placing the feet as pointing towards the target) benefits her chance of hitting the target. She may be easily able to abstract this association from her memory. The association is not a sign, but a generalized abstract idea of a function. As the golf player enters a current game and is lining up for her stroke, she can engage the association - i.e. her memory of how to position her feet to hit her target - and make a sign from it. This does not mean abiding by the recalled association. It means integrating the memory into her perception of the situation in which she holds the purpose of finding the perfect direction of her feet. In other words she will integrate this memory into her contextualization of the sign-making she performs as she outlines the exact direction of her feet (form) that will allow her a successful stroke (meaning). She 
would certainly do well to also include in the contextualization her perception of the strength of the wind for example, and of how the terrain (say a group of tall trees ahead) will affect the wind at various points of the ball's travel towards the target. All such relevant factors may jointly allow her to make the sign that pointing her feet a bit to the right of the target will allow her the effect of hitting the target accurately. If she did not integrate all the relevant factors, how sophisticated would her interaction be as she strikes? Semiosis is not a simple matter of replicating single associations then, but of integrating all and only the relevant factors (from memory and present) into a contextualization that adequately informs our signmaking as we move towards a purpose. The abstracted memory of previously made signs can maximally make part of the contextualization of a new sign.

Similarly, in communication involving language we can observe that signmaking depends on contextualization and is yet influenced by experience. Imagine that I have the purpose of understanding a message from my child left for me on the kitchen table. My first subgoal would likely be to read the message, and this first involves allowing a visual impression of the print to make me think of a sound. My recollection of how I have related my son's handwritten notations to sounds before, are part of my contextualization as I outline the notation 'skating' on the paper and allow it to guide me to think of a specific sound. I now change my purpose to that of allowing the sound to make me think of a concept and part of my contextualization of this sign-making act is an abstracted memory of how I have lately been able to relate sounds to concepts in instances of successful communication with my son, so I allow the sound to make me think of the activity 'skateboarding. I now move on to a new subgoal in my pursuit of understanding the message, carrying the purpose of finding out what he wanted me to be aware of: as I make a sign from the conceptual thought of skateboarding, I may contextualize my sign-making with my interest in knowing where he is, with the expectation that he has left the note to let me know something important for the coordination of our interaction, with the notion that my son has at this time only been back from school for maximum 15 minutes, and with the memory that he currently likes to go to the small skatepark close to our house. This allows me to make the conceptual thought of skateboarding mean that my son is currently at the skatepark. My knowledge of the word 'skating' did not determine my sign-making and could not have predicted it. In the series of contextualized sign-makings that go into moving from just one perceived linguistic expression to understood communicated meaning, my semiological actions are guided by contextual integrations of abstracted memory but not determined by them.

The perceptual ability to outline meaningful forms freely in perception makes us very creative. Say I read 'sk(o:ting' on the paper from my son instead. Due 
to my perceptual ability to outline significant forms freely, I can, for example, make a sign of the 'sk..ting' parts of the writing, supported by integrating the word 'skating' into my contextualization of the sign. The freedom to select form and meaning also allows me to understand things in alternative, say metaphorical or metonymic ways. If you tell me that your son is a mole in school, I may use the word sound to arrive at the concept of a mole but pick out only certain features in my thinking about a mole - e.g. that it likes to hide below the surface of the earth - and apply them to my imagination of your son in front of teachers.

I select a figure in the sensory stimulus or I 'carve out', as James says, a pattern in the stream of experience to suit my purpose, and then I realize how it affects my interaction potential. In language this ability of perception to freely select a figure (form or meaning) in the sensory stimuli delivered by a sound or a concept is exploited again and again. I increase, reduce or change the initial impression of something according to my purpose and other contextualization. Identified with the main character in a crime novel, I cannot satisfy my interest in knowing what to do next, with the concept of 'steps' in the hallway. So in making a sign of this concept I expand the idea I construct of what is out there!

The creation of forms and meanings relative to our purpose and other contextualization can explain both why we conduct inferences during language comprehension, how linguistic figures arise and how we can create meaning out of completely new forms. The perceptual ability to outline significant forms freely thus establishes an amazing basis for creative activity. This matches the integrational creed "For the integrationist, sign-making is the sole domain of unbounded human creativity" (Pablé 2019).

So the reason we can arrive at the notion that languages exist as fixed codes, is that we indeed engage abstracted memories of nomenclatural associations isolated from communicatively successful sign-making instances and allow them to guide us in local communicative sign-making instances. Only the signs we make by reference to these words are indeterminable because they are made in respect of other signs that guide the same interaction. We carve out both the significant form and its meaning constrained by our contextualization: our purpose, agentive capacity and other sign-making.

\section{Conclusion}

In this article I have suggested that sign-making can be understood as a fundamental part of human perception of the world. Understanding sign-making as a natural perceptual capacity seems to me to provide a simple and reasonable 
evolutionary explanation of this cognitive ability. A question worth pondering is perhaps the following: if we did not find sign-making arising in perception, then where else would the ability come from?

I have tried to show that a pragmatic account of experience, such as is presented by William James, can inform an integrational account of semiosis by detailing how we make radically indeterminate signs (i.e. by answering the question in which form(s) and how the world affects my interaction with the situation I am in), how we contextualize (i.e. by perceptually outlining an agent and a goal to be obtained as the minimal understanding of a situation) and how we integrate (i.e. by outlining a form relative to our agency and purpose (and other already integrated signs) and defining its meaning as an effect on the situational interaction potential).

I have presented a suggestion to how mental associations become involved as tools constrained by the interest in interaction with the world or with others. I have suggested that we can solve the riddle of how language can at once be stable enough to convey meaning and flexible enough to be indefinitely contextually sensitive, lies exactly in realizing that sign-making is involved in linguistic activity in a different way than we have thought: words are not signs, and do not account for the entire path between sign and comprehended language meaning. Signs are at once more plentiful, flexible and interdependent in communication activity than we have thought - captive, as we may have been held, by the idea of communication as fixed code transfer of thought. ${ }^{6}$

\section{References}

Bordo, Susan R. 1987. The Flight to Objectivity. Albany: State University of New York Press.

Cobley, Paul 2011. Mythbusting. Language Sciences 33(4): 511-516. https://doi.org/10.1016/j. langsci.2011.04.006

Cunningham, Suzanne 1996. Philosophy and the Darwinian Legacy. Rochester: University of Rochester Press.

Dewey, John 1916. Democracy and Education: An Introduction to the Philosophy of Education. New York: The Macmillan Company.

Dilthey, Wilhelm 1988. Introduction to the Human Sciences: An Attempt to Lay a Foundation for the Study of Society and History. (Betanzos, Ramon J., trans.) Detroit: Wayne State University Press

Harris, Roy 1981. The Language Myth. London: Duckworth.

Harris, Roy 1996a. Signs, Language, and Communication. New York: Routledge.

6 Acknowledgements. The author wishes to thank Adrian Pablé for most helpful comments to this article. 
Harris, Roy 1996b. The Language Connection: Philosophy and Linguistics. London: Bloomsbury Academic.

Harris, Roy 1998. Introduction to Integrational Linguistics. Oxford: Pergamon.

Harris, Roy 2009. The integrational conception of the sign. In: Harris, Roy, Integrationist Notes and Papers 2006-2008. Gamlingay: Bright Pen, 61-81.

Harris, Roy 2012. Integrating Reality. London: New Generation Publishing.

Harris, Roy; Wolf, George (eds.) 1998. Integrational Linguistics: A First Reader. Oxford: Pergamon.

James, William 1907. Pragmatism: A New Name for Some Old Ways of Thinking. New York: Longmans, Green, and Co.

James, William 2003[1912]. Essays in Radical Empiricism. New York: Courier Dover Publications.

Landgrebe, Ludwig 1973. The phenomenological concept of experience. (Welton, Donn C., trans.) Philosophy and Phenomenological Research 34(1): 1-13. https://doi.org/10.2307/ 2106776

Linell, Per 2009. Rethinking language, mind and world dialogically: Interactional and contextual theories of human sense-making. Charlotte: Information Age Publishing.

Love, Nigel 2007. Are languages digital codes? Language Sciences 29: 690-709. https://doi. org/10.1016/j.langsci.2007.01.008

Modrak, Deborah 2000. Aristotle's Theory of Language and Meaning. Cambridge: Cambridge University Press.

Noë, Alva 2004. Action in Perception. London: The MIT Press.

Pablé, Adrian 2019. Integrating the (dialogical) sign: Or who's an integrationist? Language Sciences 75: 72-85. https://doi.org/10.1016/j.langsci.2019.06.001

Pablé, Adrian; Hutton, Christopher 2015. Signs, Meaning and Experience: Integrational Approaches to Linguistics and Semiotics. (Semiotics, Communication and Cognition 15.) Berlin: De Gruyter.

Popper, Karl 1963. Conjectures and Refutations. London: Routledge.

Varela, Francisco J.; Thompson, Evan; Rosch, Eleanor 1991. The Embodied Mind: Cognitive Science and Human Experience. Cambridge: The MIT Press.

\section{Создание реальности в виде локального интерфейса - интеграционный, прагматичный подход к семиозису}

Лингвистика и семиотика традиционно отстаивают мнение, что коммуникация предполагает знаки. Интеграционная лингвистика бросает вызов этой точке зрения, опровергая онтологический статус знаков и семиотических кодов первого порядка. Однако если коммуникация не зависит от заранее установленных знаков, то каким образом происходит семиозис? И что лежит в основе интуитивно приемлемого представления о том, что коды существуют как социально переносимые структуры среди живых существ?

В статье предлагается интеграционный подход к семиозису, основанный на предположении, что производство знаков является перцептивной деятельностью. Я опираюсь на концепцию человеческого опыта Уильяма Джеймса при разъяснении 
утверждений Роя Харриса о радикальной неопределенности, контекстуальности и процессе интеграции знака. В заключение рассматривается роль ментальных ассоциаций в коммуникативной деятельности, в частности ассоциаций между звуками языка и понятиями.

\section{Reaalsuse loomine lokaalselt kujundatud liidesena - semioosi integratsiooniline, pragmaatiline selgitus}

Lingvistika ja semiootika on traditsiooniliselt toetanud seisukohta, et kommunikatsiooni eelduseks on märgid. Integratsiooniline lingvistika vaidlustab selle seisukoha, kummutades märkide ja semioloogiliste koodide esimese astme ontoloogilise staatuse. Ent kui kommunikatsioon ei sõltu eelnevalt sätestatud märkidest, siis kuidas toimub semioos? Ja mis on aluseks intuitiivselt omaksvõetavale arusaamale, et koodid eksisteerivad elusolendite seas sotsiaalselt kantud struktuuridena?

Esitan artiklis integratsioonilise ülevaate semioosist, mis põhineb oletusel, et märgiloome on pertseptuaalne tegevus. Lähtun William Jamesi inimkogemuse mõistest, selgitamaks Roy Harrise väiteid märgi radikaalse määramatuse, kontekstualiseerituse ning integratsiooniprotsessi kohta. Lõpetuseks vaatlen, millist rolli mängivad kommunikatsioonitegevuses mentaalsed assotsiatsioonid, näiteks need, mis esinevad keelehelide ja mõistete vahel. 